\title{
Formation of responsibility of a future specialist - important requirement of professional training of modern power engineering students
}

\author{
Shamardina V. ${ }^{*}$, Anishchenko M., Lazurenko 0. \\ National Technical University "Kharkiv Polytechnic Institute", Kharkiv, Ukraine
}

Received: $05.04 .2019 \quad$ Accepted: 16.04 .2019

\begin{abstract}
The paper describes experience in training professional responsibility of future power engineers through introducing a special educational course into the academic program, the course containing actual information on power facilities designing, mounting, setup, and operation in different countries. Modern industry widely employs complex engineering systems comprising a great number of various objects linked to one another, the links reflecting technological and converting processes. Even with high-level automation, reliable and long-term operation of such systems is impossible without operational personnel participation in technological process control, all the more qualified engineers are required for designing state-of-the-art facilities and retrofitting the existing ones. Operation of complex engineering systems, especially in power industry, can bring about occurrence of emergency or abnormal situations that may result in danger for people and environment. In the overwhelming majority of such cases, the cause of the emergency is the human factor, that is a mistake of those people who designed, mounted, made repairs, or operated the facilities. The engineering staff operation accuracy affects the speed of emergency response and the sequence of the standard operating conditions disturbance: whether it will be eliminated or evolve into a severe accident. That is why the essential and relevant solution is formation of professional personality of the engineer at the stage of his obtaining professional training at university. The extreme importance of this problem is proved by the rise in technological accidents (disasters) in all countries of the world. The content of professional training at a technical university must provide for students' study and practical application of techniques, skills and practices that help form special knowledge, including legal one, which will be required for future professional activity, allow avoiding possible mistakes in designing, mounting and operating technical objects, and decrease probability of fault occurrence. In this context, increasing is the role of close alliance between the specialty-training departments and industry, search for possibilities to improve efficiency of graduates' practical training directly on the basis of relevant industrial facilities, organization of education with actual examples of complex technical systems operation. Key words: safety, responsibility, risks, design, installation, operation, errors, losses.
\end{abstract}

\section{Формування відповідальності майбутнього фахівця - найважливіша вимога професійної підготовки сучасних студентів-енергетиків}

\author{
Шамардіна В. М., Аніщенко М. В., Лазуренко О. П. \\ Національний технічний університет «Харківський політехнічний інститут», Харків, Україна.
}

\begin{abstract}
Анотація. У статті викладається досвід формування професійної відповідальності майбутніх фрахівців електроенергетиків шляхом введення в навчальний план їх підготовки оригінального навчального курсу, побудованого на реальних фактах проектування, монтажу, налагодження та експлуатації енергооб'єктів різних країн світу. В сучасному виробництві великою мірою використовуються складні технічні системи зі значною кількістю різноманітних об'єктів та зв'язків між ними, які відображають технологічні та перетворювальні процеси. Навіть при високому рівні автоматизації надійна та тривала робота таких систем неможлива без участі в керуванні технологічними процесами оперативного та обслуговуючого персоналу, тим більш кваліфіковані інженери потрібні при виконанні робіт з проектування нових та модернізації існуючих об'єктів. Робота складних технічних систем, особливо в енергетичному секторі промисловості, буває пов'язана 3 виникненням аварійних або нештатних ситуацій, наслідок яких може привести до ризиків життю людини та оточуючого середовища. Причиною аварій, в переважній більшості випадків, $€$ «людський фактор», тобто
\end{abstract}

\footnotetext{
Corresponding Author: Shamardina Vira. Phone: +38(057)7076974 .E-mail: verascha@i.ua National Technical University "Kharkiv Polytechnic Institute", Kirpichova st., 2, Kharkov, Ukraine, 61002.

Відповідальний автор: Шамардіна Віра Миколаївна. Тел. +38(057)7076974. E-mail: verascha@i.ua Національний технічний університет «Харківський політехнічний інститут», вул. Кирпичова, 2, м. Харків, Україна, 61002.
} 
помилки людей, які проектували об'єкти, монтували їх, проводили ремонти обладнання або ж займалися їх експлуатацією Від правильності дій інженерних кадрів залежить, чи буде швидко ліквідовано порушення штатного режиму або воно перейде в серйозну аварію, яка здатна спричинити за собою тяжкі наслідки. Тому на часі дуже важливим є вирішення завдання, яке пов'язане з формуванням професійної особистості інженера ще на етапі його навчання в навчальному закладі. Підтвердженням надзвичайної важливості цієї проблеми $\epsilon$ зростання числа технічних (техногенних) катастроф у всіх країнах світу. Зміст підготовки в технічних вишах має передбачати вивчення й практичне використання студентами методів, прийомів і навичок, які допомагають формувати спеціальні знання, в тому числі й правові, що необхідні для подальшої практичної діяльності, які б виключали можливі помилки при проектуванні, монтажі та експлуатації технічних об'єктів і знижували ймовірність аварій на них. В цьому контексті зростає роль зміцнення зв'язків випускаючих кафедр 3 підприємствами, пошуку можливостей підвищення ефективності практичної підготовки випускників безпосередньо на виробничому обладнанні, організації навчання на конкретних прикладах експлуатації складних технічних систем.

Ключові слова: безпека, відповідальність ризики, проектування, монтаж, експлуатація, помилки, збитки.

\title{
Формирование ответственности будущего специалиста - важнейшее требование профессиональной подготовки современных студентов- энергетиков
}

\author{
Шамардина В. Н., Анищенко Н. В., Лазуренко А. П.
}

Национальный технический университет «Харьковский политехнический институт», Харьков, Украина.

\begin{abstract}
Аннотация. В статье излагается опыт формирования профессиональной ответственности будущих специалистов - электроэнергетиков путем введения в учебный план их подготовки оригинального учебного курса, построенного на реальных фактах проектирования, монтажа, наладки и эксплуатации энергообъектов различных стран мира. В современном производстве широко используются сложные технические системы с большим количеством различных объектов и связей между ними, которые отражают технологические и преобразовательные процессы. Даже при высоком уровне автоматизации надежная и длительная работа таких систем невозможна без участия в управлении технологическими процессами оперативного и обслуживающего персонала, тем более квалифицированные инженеры нужны при выполнении работ по проектированию новых и модернизации существующих объектов. Работа сложных технических систем, особенно в энергетическом секторе промышленности, бывает связана с возникновением аварийных или нештатных ситуаций, вследствие которых возникают риски для жизни человека и окружающей среды. Причиной аварий, в подавляющем большинстве случаев, является «человеческий фактор», то есть ошибки людей, которые проектировали объекты, монтировали их, проводили ремонты оборудования или занимались их эксплуатацией. От правильности действий инженерных кадров зависит, как быстро будут устранены нарушения штатного режима или они перейдут в серьезную аварию, которая способна повлечь за собой тяжелые последствия. Поэтому актуальным и очень важным является решение задачи, которое связано с формированием профессиональной личности инженера еще на этапе его обучения в учебном заведении. Подтверждением чрезвычайной важности этой проблемы является рост числа технических (техногенных) катастрофр во всех странах мира. Содержание подготовки в технических вузах должно предусматривать изучение и практическое использование студентами методов, приемов и навыков, которые помогают формировать специальные знания, в том числе и правовые, необходимые для дальнейшей практической деятельности, позволяющие исключить возможные ошибки при проектировании, монтаже и эксплуатации технических объектов и снизить вероятность аварий на них. В этом контексте возрастает роль укрепления связей выпускающих кафедр с предприятиями, поиска возможностей, способствующих повышению эффрективности практической подготовки выпускников непосредственно на производственном оборудовании, организации обучения на конкретных примерах эксплуатации сложных технических систем.

Ключевые слова: безопасность, ответственность риски, проектирование, монтаж, эксплуатация, ошибки, убытки.
\end{abstract}

\section{Bcmyn}

Традиційна система підготовки фахівців-енергетиків у технічних вишах нашої країни включає в себе їх теоретичну і практичну підготовку за освітніми програмами в межах діючих навчальних планів. Вона побудована, в основному, на передачі студенту наукових й технічних знань і, практично, не готує його до специфічних реалій життя, з якими майбутній спеціаліст зіштовхнеться на виробництві.

Взагалі це стосується не тільки технічних вищих навчальних закладів. Найбільш актуальною ця проблема стає, коли мова йде про підготовку майбутніх спеціалістів в університетах країни для галузей 
промисловості, робота в яких пов'язана з деякими ризиками для життя людини та оточуючого середовища. Перш за все, це складні технічні системи з великою кількістю різноманітних об'єктів та зв'язків між ними, які відображають технологічні та перетворювальні процеси. До таких галузей слід віднести: енергетику, металургію, хімічну промисловість, підприємства, які обслуговують військовий і космічний комплекси та інше. Їх надійна та тривала робота неможлива без участі в управлінні технологічними процесами оперативного та обслуговуючого персоналу, навіть при високому рівні автоматизації, не кажучи вже про роботи з проектування нових та модернізації існуючих об'єктів.

Теоретична підготовка енергетиків включає в себе набір традиційних навчальних дисциплін, а також деякі нові спеціальні дисципліни, що базуються на досягненнях комп'ютерної математики, IT технологій і сучасної обчислювальної техніки. Що ж стосується практичної підготовки, то, на жаль, її якість за останній час впала внаслідок погіршення умов для організації якісних виробничих та переддипломних практик, обмеження можливостей для стажування на підприємствах викладачів.

Разом з тим, життя ставить все нові і нові завдання з вирішення серйозних проблем, одна з яких пов'язана з формуванням професійної особистості інженера ще на етапі його навчання в навчальному закладі. Підтвердженням надзвичайної важливості цієї проблеми $є$ зростання числа технічних (техногенних) катастрофр у всіх країнах світу.

Остання чверть минулого і початок 21 століття супроводжувалося зростанням аварій на енергетичних підприємствах. Досить назвати аварії на атомних електростанціях «Три Айленд» (США), Чорнобильська (Україна), Фукусіма (Японія), на Саяно-Шушенській ГЕС (Росія), руйнівні аварії на гідроспорудах Баосянь (Китай), вибухи і пожежі на заводах, що виготовляють боєприпаси, серйозні аварії на транспорті, на морських бурових установках (Норвегія, США). Вони привели не тільки до величезних матеріальних збитків, але й до сотень і тисяч людських жертв.

Численні комісії, які розслідували аварії на технічних об'єктах, в кінцевому підсумку робили один і той же висновок: причиною аварій, в переважній більшості випадків був «людський фактор», тобто на різних етапах життя технічного об'єкту або системи були помилки людей, які проектували ці об'єкти, монтували їх, проводили ремонти обладнання або ж займалися їх експлуатацією.

Мета роботи. Виявити причини недостатньої підготовки майбутніх енергетиків до передбачення і не припущення умов виникнення нештатних і аварійних режимів роботи енергетичного обладнання, а також знайти шляхи вирішення цієї проблеми.

\section{II Матеріал і методи дослідження}

Постає питання, хто і коли допускає помилки при підготовці фрахівців, не виховуючи в них профресійної відповідальності за свої дії й відповідальності перед суспільством за наслідки своєї роботи. При найближчому розгляді цієї проблеми стає очевидним, що велика вина в цьому лягає на вищі навчальні заклади, які формували свого студента як фахівця, але не виховували його як професійну особистість [1].

Не применшуючи значення формування людини, як соціальної особистості, автори вважають, що професійний портрет особистості технічного професіонала повинен створюватися в технічних вищих навчальних закладах тими викладачами, які при активній допомозі фахівців-психологів навчають студента його спеціальності, добре орієнтуються в області діяльності майбутнього фахівця.

Тут потрібна розробка методів, прийомів і навичок, які допомогли б викладачам вищих технічних закладів на тлі передачі спеціальних знань формувати у студентів необхідні їм для подальшої практичної діяльності професійні якості, які б виключали можливі помилки при проектуванні, монтажі та експлуатації технічних об'єктів і знижували ймовірність аварій на них.

На наше тверде переконання ця задача під силу тільки інженерній педагогіці та повинна входити як складова в загальну їі мету - навчання технічних фрахівців.

Слід відзначити, що автори не єдині в цьому переконанні, і підтвердженням цьому служать ряд доповідей, представлених на симпозіумі IGIP в Словаччині [3-5].

Насамперед, необхідно чітко визначити якості фахівця, які повинні стати його професійними якостями і забезпечити йому подальшу ефективну роботу на дорученій ділянці. При виникненні аварійної ситуації персонал має дуже мало часу на пошук, прийняття й реалізацію єдино вірного 
рішення. Саме від правильності дій інженера залежить, чи буде швидко ліквідовано порушення штатного режиму або воно перейде в серйозну аварію, яка здатна спричинити за собою тяжкі наслідки.

Перелічені характеристики інженерних проблем певною мірою визначають зміст підготовки студентів технічних вишів.

\section{III Результати}

Для забезпечення відповідної підготовки інженерів-енергетиків в Національному технічному університеті «Харківський політехнічний інститут» на кафедрі «Електричні станції» був розроблений і впроваджений в навчальний процес спеціальний курс «Основи енергетичної та екологічної безпеки і відповідальності фрахівця», програма якого включає аналіз аварій, що сталися на вітчизняних й зарубіжних електростанціях і в енергосистемах, ретельний пошук їх причин, організацію окремих напрямків діяльності фрахівців-електроенергетиків (проектування станцій, конструювання і вибір обладнання, його транспортування на місце установки, монтаж й налагодження, пуск та експлуатація). Виявляються можливі помилки при виконанні названих вище робіт з численними прикладами, які мали місце на практиці, даються рекомендації щодо попередження таких помилок, вивчаються правові питання особистої відповідальності за дії, що призводять до аварій або до псування обладнання. Навчання підкріплюється численними екскурсіями на заводи, де виробляється енергетичне i електротехнічне обладнання, а також на діючі електричні станції та підстанції.

Розроблена програма нового навчального курсу пройшла широке рецензування в галузевих проектних інститутах («Енергопроект», «Укргідропроект» та ін.), у відділах і службах експлуатації АК «Харківобленерго» і Запорізької АЕС, у розробників та постачальників енергообладнання (ВАТ «Турбоатом» і ВАТ «Електроважмаш») та в Міністерстві палива та енергетики України. Введення цієї навчальної дисципліни в навчальний план підготовки магістрів 3 електроенергетики знайшло одностайну й широку підтримку всіх перелічених вище організацій.

Програма навчальної дисципліни включає ряд модулів. Перший з них - «Основні положення системи забезпечення енергетичної та екологічної безпеки» - включає матеріали для формування у майбутніх фахівців знань про організаційну структуру управління енергетичною галуззю, про державні організації і установи, а також державних керівників, які мають безпосереднє відношення до енергетики держави в частині розробки та прийняття стратегії й політики її розвитку, рішень про модернізацію й будівництво енергетичних об'єктів та фінансування електроенергетичної галузі, а також прийняття законів про енергетику, тарифну політику в державі тощо. Показано взаємини між цими структурами при вирішенні різних питань в енергетиці [2,3]. На реальних фактах минулих років демонструється негативний результат помилок, які були допущені керівниками цих установ і керівниками вищих державних органів, наприклад, при виборі місця будівництва енергооб'єктів (Каховська ГЕС, Кримська АЕС).

Наступний модуль дисципліни присвячений запобіганню ризиків при проектуванні енергооб'єктів. Наводяться відомості про основні проектні інститути та організації, які займаються проектуванням теплових, гідравлічних, атомних, вітрових і сонячних електростанцій, електричних підстанцій та про їх структури. На прикладах реально допущених прорахунків показується до чого вони приводять, оцінюються їх наслідки і втрати з точки зору техніки, екології, суспільства. Даються практичні рекомендації щодо запобігання найбільш поширених помилок при проектуванні енергооб'єктів.

У програму дисципліни включено розділи щодо запобігання ризиків при розробці енерго- i електроустаткування для енергооб'єктів, при транспортуванні до місця монтажу на об'єктах, а також при проведенні налагодження для включення в експлуатацію.

Особливу увагу приділено питанням щодо уникнення ризиків від неправильних дій оперативного персоналу, який експлуатує електричні станції та підстанції. Практика показує, що загальна кількість порушень і аварій на енергооб'єктах (майже 70\%) пов'язана саме з порушеннями правил експлуатації. На конкретних прикладах таких порушень студентам пояснюється, до яких наслідків вони призводять (аварія на ЧАЕС та інші) і як можна було уникнути цих аварій [3-6].

У програмі дисципліни належне місце відводиться правовим питанням, пов'язаним з оцінкою неправильних дій фрахівців в реальних умовах виробництва і з оцінкою їх особистої відповідальності.

На практичних заняттях студенти розглядають і аналізують протоколи виникнення і розвитку окремих аварій, що сталися на реальних електричних станціях і в енергосистемах. При цьому 
зазначаються конкретні помилки персоналу цих енергооб'єктів на різних стадіях життя цих об'єктів (проектування, виготовлення і монтажу обладнання, їх експлуатації і т.д.).

Широко використовуються на практичних заняттях ділові та рольові ігри в умовах діючих енергооб'єктів, студенти набувають навичок своєї поведінки на попередження та ліквідацію можливих аварій.

За відгуками керівників підприємств, куди прийшли випускники кафедри, виявилось, що той, хто прослухав цей курс, дуже швидко адаптувався на своєму робочому місці й показав більш відповідальне ставлення до виконання завдань, що доручаються, ніж це було з випускниками минулих років.

\section{IV Обговорення}

В літературних джерелах, присвячених висвітленню актуальних питань енергетичної безпеки держави, в основному, розглядаються глобальні тенденції у розвитку енергетики, дослідження проблем оптимізації енергозабезпечення і енергонезалежності України, напрямки енерго-заощадження та шляхи забезпечення енергоефективності тощо [7]. В той же час питанням впливу «людського фактору» на енергобезпеку приділяється недостатньо уваги. Тому звернення до цієї проблеми $є$ своєчасним і актуальним.

\section{V Висновки}

1. Виховання професійної особистості майбутнього фахівця з високою відповідальністю за результати своєї праці є найважливішим завданням закладів вищої освіти. В сучасних умовах для прийняття відповідальних рішень важливо глибоке розуміння інженером усіх виробничих процесів, їх взаємозв'язків, можливих ризиків нештатних ситуацій, особливо при експлуатації складного енергетичного обладнання.

2. Вирішенню проблеми формування відповідальності інженерів-енергетиків певною мірою сприяє введення в навчальний план підготовки магістрів зі спеціальності 141-«Енергетика, електротехніка та електромеханіка» спеціальної навчальної дисципліни «Основи енергетичної та екологічної безпеки і відповідальності фрахівців», зміст якої описано в цій статті.

3. Роботодавці відзначають, якщо випускники опанували названу дисципліну, вони мають більшу впевненість в своїх знаннях, на робочих місцях приймають більш обірунтовані рішення й не бояться відповідальності за їх реалізацію.

\section{Бібліографрічні посилання}

[1] Артюх С. Ф., Лазуренко О. П. Виховання професійних і спеціальних психофізіологічних якостей у майбутніх інженерів - запорука зниження ризиків техногенних катастроф, «Вища школа»,Київ, 2011, №3.

[2] Зеркалов Д. В. Енергетична безпека : Монографія. Електрон. дан. К.: Основа, 2012.

[3] Makarov Evgeniy. The formation of professional competencies of road construction engineers in the process of theoretical and practical training integration. Proceedings of the Joint International IGIP - SEFI Annual conference 2010. Slovakia. Trnava p. 67-69

[4] Hagovska Andrea. Future competencies - experience and practice. Proceedings of the Joint International IGIP - SEFI Annual conference 2010. Slovakia. Trnava p. 407-409.

[5] Szczuka Dorna, Liliana; Trzcielinski, Stefan; Przewazna - Krzeminska, Agata; Szkutnik, Jerzy. Professionally qualified graduate of a technical university. Proceedings of the Joint International IGIP - SEFI Annual conference 2010. Slovakia. Trnava p. $424-425$.

[6] Скляров В. Ф. Завтра був Чорнобиль. К. : ННЦ «ІАЕ», 2011. 288 с.

[7] Державна інспекція з експлуатації електричних станцій і мереж. Інформаційні та аналітичні матеріали. 1991-2009 р.р. / Гутаревич О.Т. ПП «Дар-Гранд». Київ. 2009.

[8] Енергетична безпека України та світу: реферативний огляд / уклад. Н.В. Добра, Є.О. Корнілова, Ж.B. Самохіна. URL : http://www.nbuv.gov.ua/sites/default/files/all_files/references/201504/vtdo_ro_4.pdf (дата звернення 10.03.2019).

[9] Техногенна безпека АЕС : навч. посібник / А. Б. Тарнавський, Р. Ю. Сукач, Ю. Г. Сукач ; Держ. служба України 3 надзвичайних ситуацій, Львів. держ. ун-т безпеки життєдіяльності. Львів, 2014. Ч. 1. 371 с.

[10] Двадцять п'ять років Чорнобильської катастрофи. Безпека майбутнього : зб. доп., висновки і рек. Міжнар. конф., 20 22 квіт. 2011 р., Київ. Ч. 2 / ред.: Л. В. Перепелятникова; Всеукр. НДІ цивіл. захисту населення і територій від надзв. ситуацій техног. та природ. характеру. К., 2011. 383 с.

[11] Топольницький М. В. Атомні електричні станції : підручник. Наук.-метод. центр вищ. освіти М-ва освіти і науки України. Львів: Бескид Біт, 2005. 523с. 
[12] Українська енергетика : сайт. URL : http://ua-energy.org (дата звернення 10.03.2019).

[13] Кравченко Р. А. Правове забезпечення зниження ризику надзвичайних ситуацій техногенного та природнього характеру в Україні: стан, проблеми, перспективи / Вісник НАДУ при Президентові України (Серія "Державне управління"). 2017, № 3. С. 38 - 44.

[14] Ядерні та радіаційні технології в Україні: можливості, стан і проблеми впровадження : зб. наук. статей / ред. : В. П. Горбулін ; Рада нац. безпеки і оборони України, Ін-т пробл. нац. безпеки, Укр. ядер. товариство. Київ: Пріоритети, 2011. $284 \mathrm{c}$.

[15] Данілін О. М.Техногенна безпека об'єктів та технологій. URL : http://books. nuczu. edu.ua/ download.php?rec=5551\&mode=1 (дата звернення 10.03.2019).

[16] Гіроль М. М., Ниник Л. Р., Чабан В. Й. Техногенна безпека : підручник. Рівне: УдУВГП, 2004. 452 c.

[17] Стоєцький В. Ф., Дранишников Л. В., Єсипенко А. Д. Управління техногенною безпекою об'єктів підвищеної небезпеки. Тернопіль : Видавництво Астон, 2005. 408 с.

[18] Національний класифікатор надзвичайних ситуацій ДК 019-2010 від 11.10.2010 va457609-10.

[19] Про об’єкти підвищеної небезпеки: Закон України від 26.04.2014 №2245-ІІІ.

[20] Постанова Кабінету Міністрів України від 11.07.02p. №956 «Порядок ідентифікації та обліку об’єктів підвищеної небезпеки».

\section{References}

[1] Artjuh, S. F., Lasurenko, O. P. (2011). Vyhovannja profesiynyh i spezialnyh psyhofisiologichnyh jakostey u maybutnih ingeneriv - saporuka snygennja rysykiv tehnogennyh katastrof. "Wyshcha shkola",Kyiv, №3. [in Ukrainian]

[2] Serkalov, D. W. (2012). Energetychna bespeaka : monografija. Osnova, Kyiv. [in Ukrainian]

[3] Makarov, E. (2010). The formation of professional competencies of road construction engineers in the process of theoretical and practical training integration. Proceedings of the Joint International IGIP - SEFI Annual conference. Slovakia. Trnava $p$. 67-69.

[4] Hagovska, A. (2010). Future competencies - experience and practice. Proceedings of the Joint International IGIP - SEFI Annual conference. Slovakia, Trnava, 407-409.

[5] Szczuka, D. L., Trzcielinski, S., Przewazna-Krzeminska, A., Szkutnik, J. (2010). Professionally qualified graduate of a technical university. Proceedings of the Joint International IGIP - SEFI Annual conference. Slovakia. Trnava, p. $424-425$.

[6] Skljarov, W. F. (2011). Savtra buv Chernobyl. NNZ "IAE", Kyiv, 288 c. [in Ukrainian]

[7] Gutarevich, T. (2009). Dergavna inspekzija s ekspluataziji elektrichnyh stanwiy I mereg. Informaziyni ta analitychni materialy.1991-2009 r.r. PP "Dar-Grand", Kyiv. [in Ukrainian]

[8] Dobra, N. W., Kornilova, E. O., Camohina, G. W. (2015). Energetychna bezpeka Ukrayiny ta svitu: referatyvnyj oglyad. URL: http://www.nbuv.gov.ua/sites/default/files/all_files/references/201504/vtdo_ro_4.pdf (accessed 10.03.2019). [in Ukrainian]

[9] Tarnavskyy, A. B., Sukach, R. J., Sukach, J. G. (2014). Tehnogenna bezpeka AES : navch. posibnyk. Derg. slugba Ukrainy s nadzvychaynyh sytuaziy, Lviv. derg. un-t bespeky gyttedijalnosti. Lviv, part. 1. 371 p. [in Ukrainian]

[10] Dvadzat pjat pokiv Chornobylskoy katastrofy. Bespeka maybutnjogo : sb. dop., vysnovky I rek. Mignar. Konf., $20-25$ kvst. 2011 r., Kyiv. Ch. 2 / L.V. Perepeljatnikova; Vseukr. NDI zivil. Sahystu naselennja I teritiriy vid nadzv. Situaziy tehnog. Ta prypod. Harakteru. K., 2011. 383 p. [in Ukrainian]

[11] Topolnizkiy, M. V. (2005). Atomni elektrichni stanzii : pidruchnyk. Nauk.-metod. Zentr vysch. Osvity M-va osvity I nauky Ukrainy. Lviv: Beskid Bit, 523 p. [in Ukrainian]

[12] Ukrainska energetyka. URL : http://ua-energy.org. (accessed 10.03.2019). [in Ukrainian]

[13] Kravchenko, R. A. (2017). Pravove sabespechennja snygennja pysyky nadsvychainyh situaziy tehnogennogo ta pryrodnjogo harakteru v Ukraini : stan, problemy, perspektyvy. Visnyk NADU pry Presydentovi Ukrainy (Serija "Dergavne upravlinnja")., № 3,38 - 44. [in Ukrainian]

[14] Gorbulin, V. P. (Ed.) (2011). Jaderni ta radiaziyni tehnologii v Ukraini: Moglyvosti, stan i problemy vprovadgenniz : sb. nauk. Statey. Rada naz. bespeky I oborony Ukrainy, In-t probl. Bespeky, Ukr. jader. tovarystvo. Priorytety, Kyiv, 284. [in Ukrainian]

[15] Danilin, O. M. (2019). Tehnogenna bespeka obektiv ta tehnologiy. URL: books.nuczu.edu.ua/ download.php?rec= $5551 \&$ mode $=1$ (accessed 10.03.2019).

[16] Girol, M. M., Nynyk, L. R., Chaban, V. J. (2004). Tehnogenna bespeka: pidruchnyk. UDUVGP, Rivne, 452. [in Ukrainian]

[17] Stojezkiy, V. F., Dranischnikov, L. V., Esipenko, A. D. (2005). Upravlinnja tehnogennoju bespekoju obektiv pidvyschennoj nebespeky. Vydavnyztvo Aston, Ternopil, 408. [in Ukrainian]

[18] Nazionalnyy klasifikator nadsvychaynyh situaziy ДK 019-2010 vid 11.10.2010 va457609-10.

[19] Pro objekty pidvyschenoj nebespeky: Zakon Ukrainy vid 26.04.2014 №2245-III.

[20] Postanova Kabinetu Ministriv Ukrainy vid 11.07 .02 r. № 956 "Porjadok identyfikazii ta obliku obektiv pidvyschennoj nebespeky". 


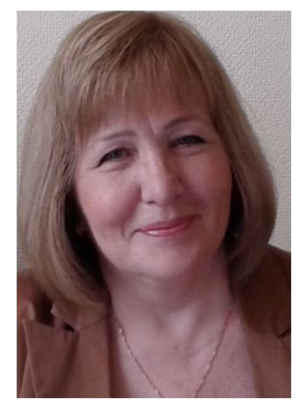

\section{Шамардіна Віра Миколаївна,}

Кандидат технічних наук, доцент, профессор,

Національний технічний університет «Харківський політехнічний інститут»,

вул. Кирпичова, 2, м. Харків, Україна, 61002.

Тел.+38(057)7076974. E-mail: verascha@i.ua

\section{Shamardina Vira Mykolaivna,}

Cand.Sc.(Eng.), Associate Professor, Professor,

National Technical University "Kharkiv Polytechnic Institute",

Kirpichova st., 2, Kharkov, Ukraine, 61002,

Tel. +38(057)7076974. E-mail: verascha@i.ua

\section{ORCID: 0000-0002-9274-6517 \\ Scopus ID: 6504086734}

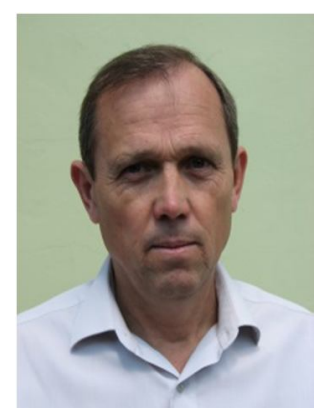

\section{Аніщенко Микола Васильович,}

Кандидат технічних наук, доцент, профресор,

Національний технічний університет «Харківський політехнічний інститут»,

вул. Кирпичова, 2, м. Харків, Україна, 61002.

Тел.+38(057)7076445. E-mail: annikolay@ukr.net

\section{Anishchenko Mykola Vasylovych.}

Cand.Sc.(Eng.), Associate Professor, Professor,

National Technical University "Kharkiv Polytechnic Institute",

Kirpichova st., 2, Kharkov, Ukraine, 61002,

Tel. +38(057)7076445. E-mail: annikolay@ukr.net

\section{ORCID: 0000-0002-2720-3671}

Scopus ID: 57202581262

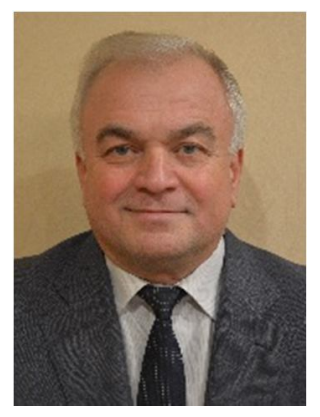

\section{Лазуренко Олександр Павлович,}

Кандидат технічних наук, доцент, професор,

Національний технічний університет «Харківський політехнічний інститут»,

вул. Кирпичова, 2, м. Харків, Україна, 61002.

Тел. +38(057)7076588. E-mail: lazurenkoAP@i.ua

\section{Lazurenko Oleksandr Pavlovych,}

Cand.Sc.(Eng.), Associate Professor, Professor,

National Technical University "Kharkiv Polytechnic Institute",

Kirpichova st., 2, Kharkov, Ukraine, 61002,

Tel. +38(057)7076588. E-mail: lazurenkoAP@i.ua

ORCID: 0000-0002-4409-629X

Researcher ID: E-9039-2016

Scopus ID: 56193989000

\section{Citation (APA):}

Shamardina, V., Anishchenko, M., Lazurenko, O. (2019). Formation of responsibility of a future specialist - important requirement of professional training of modern power engineering students. Engineering and Educational Technologies, 7 (2), 90-96. doi: https://doi.org/10.30929/2307-9770.2019.07.02.09

\section{Цитування (ДСТУ 8302:2015):}

Шамардіна В. М., Аніщенко М. В., Лазуренко О. П. Формування відповідальності майбутнього фахівця - найважливіша вимога професійної підготовки сучасних студентів-енергетиків / Інженерні та освітні технології. 2019. Т. 7. № 2. С. 90-96. doi: https://doi.org/10.30929/2307-9770.2019.07.02.09

Обсяг статmі: $\quad$ сторінок - 7 ; умовних друк. аркушів - 1,014. 